\title{
Pengujian Aktivitas Antioksidan Ekstrak Daun Ulin (Eusideroxylon zwageri) dengan Menggunakan Metode DPPH
}

\author{
Antioxidant Activity of Ulin Leaves Extract (Eusideroxylon zwageri) Using DPPH Method
}

\author{
Farida Aryani*, Firna Novari, Netty Maria Naibaho, Periani Paurru \\ Jurusan Teknologi Pertanian, Politeknik Pertanian Negeri Samarinda, Indonesia.
}

*Corresponding Author: ary_ani02@yahoo.com

\begin{abstract}
Abstrak
Antioksidan merupakan senyawa pemberi elektron atau reduktan, senyawa ini memiliki berat molekul kecil, tetapi mampu menginaktivasi berkembangnya reaksi oksidasi dengan cara mencegah terbentuknya radikal bebas. Salah satu tumbuhan yang memiliki potensi sebagai antioksidan alami adalah ulin (Euxyderoxilon zwageri). Penelitian ini bertujuan unutk mengetahui aktivitas antioksidan yang terdapat pada ekstrak daun muda dan daun tua terhadap radikal DPPH (1, 1-diphenyl-1-picrylhidrazyl) menggunakan UVVis Spektrofotometer. Simplisia daun masing-masing diekstrak menggunakan metanol pada suhu kamar, kemudian dilakukan pemekatan ekstrak menggunakan vacuum rotary evaporator sehingga diperoleh ekstrak kasar. Analisis fitokimia dilakukan untuk mengidentifikasi golongan senyawa metabolit sekunder yang meliputi flavonoid, alkaloid, tanin, saponin terpenoid dan steroid. Untuk mengetahui aktivitas antioksidan pengujian dilakukan dengan membuat seri konsentrasi larutan ekstrak yang bertujuan untuk menghitung nilai $I_{50}$, yaitu konsentrasi dimana contoh uji mampu menghambat $50 \%$ radikal bebas. Hasil analisis fitokimia menunjukkan bahwa daun muda daun tua memiliki kandungan fitokimia yang sama yaitu Flavonoid, Tanin, Saponin, Terpenoid, sedangkan Alkaloid dan Steroid tidak terdeteksi. Aktivitas antioksidan diperoleh $\mathrm{IC}_{50}$ daun muda adalah 22.93 ppm, daun tua adalah $13.31 \mathrm{ppm}$, dan Ascorbic acid sebagai kontrol positif memiliki nilai $\mathrm{IC}_{50}$ sebesar $7.08 \mathrm{ppm}$. Aktivitas Antioksidan daun ulin termasuk dalam kategori kuat karena daun muda maupun daun tua memiliki nilai $I C_{50}$ dibawah 100 ppm.
\end{abstract}

Kata kunci : Daun ulin, Euxyderoxilon zwageri, Antioksidan, DPPH, Fitokimia

\begin{abstract}
Antioxidants are electron-donating compounds or reductants, these compounds have small molecular weights, but can deactivate the development of oxidation reactions by preventing the formation of free radicals. One of the plants that have potential as natural antioxidants is the Ulin leaf (Eusideroxylon zwageri). This study aims to determine the antioxidant activity of the extracts of young and old leaves of Ulin plants against DPPH radicals (1, 1-diphenyl-1-picrylhydrazyl) using a UV-Vis Spectrophotometer. Both young and old leaves were extracted using methanol at room temperature then concentrated using a vacuum rotary evaporator to obtain a crude extract. Phytochemical analysis was conducted to identify the secondary metabolite compounds which include flavonoids, alkaloids, tannins, terpenoid saponins, and steroids. To determine the antioxidant activity, the test was carried out with series concentrations aimed at calculating the $I C_{50}$ value, the concentration at which the test sample was able to inhibit $50 \%$ of the free radical DPPH The phytochemical analysis showed that young and old leaves contained the same phytochemical content, specifically Flavonoids, Tannins, Saponins, terpenoids, while Alkaloids and steroids were not detected. The antioxidant activity test showed that the $I C_{50}$ value of young leaves, old leaves, and Ascorbic acid as the positive control were $22.93 \mathrm{ppm}, 13.31 \mathrm{ppm}$, and $7.08 \mathrm{ppm}$ consecutively. This result shows that Ulin leaves are in a strong category because both young and old leaves have an IC 50 value of less than $100 \mathrm{ppm}$.
\end{abstract}

Keywords: Ironwood leaf, Euxyderoxilon zwageri, Antioxidant, DPPH, Phytochemicals

\section{PENDAHULUAN}

Dewasa ini, dunia kedokteran dan kesehatan banyak membahas tentang antioksidan dan radikal bebas. Radikal bebas sudah menumpuk dalam rata-rata tubuh orang sekarang, lalu merusak. Hal ini disebabkan karena radikal bebas sudah beredar dimana-mana, di polusi udara, air, makanan, minuman, pestisida, obat-obatan, asap rokok, radiasi, cahaya matahari, dan gelombang elektromagnetik peralatan elektronik. Semua sudah mengepung tubuh kita. Akibatnya timbul penyakit degeneratif 
seperti jantung koroner, rematik, katarak, kanker, dan stroke.

Antioksidan merupakan suatu substansi yang pada konsentrasi kecil secara signifikan mampu menghambat atau mencegah oksidasi pada substrat yang disebabkan oleh radikal bebas (Isnindar, dkk, 2011). Radikal bebas merupakan molekul yang sangat reaktif karena memiliki elektron yang tidak berpasangan dalam orbital luarnya sehingga dapat bereaksi dengan molekul sel tubuh dengan cara mengikat elektron molekul sel tersebut (Utomo, dkk, 2008). Radikal bebas yang dihasilkan secara terus menerus selama proses metabolisme normal, dianggap sebagai penyebab terjadinya kerusakan fungsi sel-sel tubuh yang akhirnya menjadi pemicu timbulnya penyakit degenerative (Juniarti, dkk, 2009).

Antioksidan terdiri dari dua macam yaitu antioksidan alami dan antioksidan sintetik. Antioksidan sintetik antara lain butyl hidroksilanisol (BHA), butyl hidroksitoluen (BHT), dan propol gallat. Efek penggunaan antioksidan secara berlebihan bagi kesehatan menyebabkan lemah otot, mual, pusing, dan kehilangan kesadaran. Sedangkan penggunaan pada dosis rendah secara terus menerus menyebabkan tomor kandung kemih, kanker sekitar lambung, dan kanker paru-paru (Cahyadi 2009).

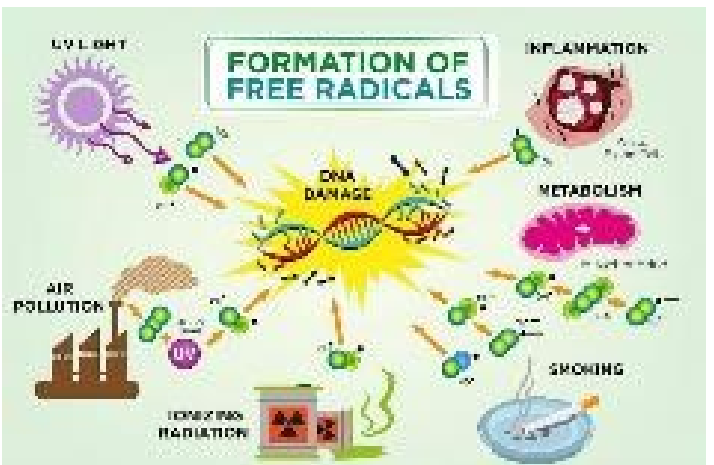

Gambar 1. Terbentuknya Radikal Bebas ( Sumber : https://doktersehat.com/caramenangkal-radikal-bebas/)

Salah satu tumbuhan yang memiliki potensi sebagai tumbuhan obat adalah tumbuhan ulin. Khasiat ini terutama dimanfaatkan oleh suku Dayak di Kalimantan. Buah ulin mengandung vitamin dan mineral yang dapat dijadikan minyak untuk mencegah kerontokan dan menghitamkan rambut. Rebusan akar dan daunnya dimanfaatkan sebagai obat kuat, bijinya dihaluskan dan dimanfaatkan sebagai obat bengkak. Pucuk daun ulin dapat juga dimakan mentah sebagai lalapan sekaligus untuk mengobati sakit pinggang (Hidayat,dkk., 2016).

Berdasarkan uraian diatas maka dilakukan penelitian untuk mengetahui potensi aktivitas antioksidan dari ekstrak metanol daun ulin terhadap radikal DPPH yang dinyatakan dalam $\mathrm{IC}_{50}$. Penelitian ini juga diharapkan dapat memberi informasi tentang manfaat dari daun ulin yang dapat digunakan sebagai alternatif dalam pengembangan obat-obat alami sebagai pencegah atau terapi terhadap penyakit degenerative yang disebabkan oleh radikal bebas.

\section{METODE PENELITIAN}

Penelitian dilakukan di Laboratorium Sifat Kayu Dan Analisis Produk Jurusan Teknologi Pertanian, Politeknik Pertanian Negeri Samarinda. Bahan baku yang digunakan dalam penelitian adalah daun ulin muda (pucuk) dan daun ulin tua yang diambil dari lingkungan kampus Politeknik Pertanian Samarinda.

Bahan kimia yang digunakan meliputi etanol, dimetilsulfoksida (DMSO), aquades, larutan DPPH, (1,1-diphenyl-2-picrylhydrazyl), natrium hidroksida, asam asetat anhidrid, asam sulfat, asam klorida, timbal asetat, pereaksi dragendorff, , $\mathrm{H} 2 \mathrm{SO} 4$ pekat, $\mathrm{HCl} 0,2$ $\mathrm{N}$, aquadest, dan larutan standar Ascorbic acid.

Peralatan yang digunakan dalam penelitian ini adalah : pisau, blander, shaker, corong, timbangan analitik, rotary vacuum evaporator, spektrofotometer, beaker glass sebagai ukuran, gelas ukur, Erlenmeyer, botol sampel, Cuvette, pipet pastur, pipet mikro, dan tabung reaksi.

\section{Pembuatan Simplisia}

Pembuatan simplisia diawali dengan pengumpulan bahan baku berupa sampel daun muda segar dan daun tua segar. Daun dilepas dari tangkainya, dicuci bersih dan dikering anginkan. Setelah itu dilakukan pengecilan ukuran menjadi serbuk dengan menggunakan blender. Selanjutnya serbuk simplisia yang dihasilkan disimpan dalam wadah kedap udara dan siap untuk digunakan. 


\section{Proses Ekstraksi}

Metode ekstraksi yang digunakan yaitu ekstraksi dingin menggunakan pelarut metanol. Ekstraksi dilakukan dengan melarutkan simplisia, dengan rasio serbuk: pelarut (1:10). Ekstraksi dilakukan dengan merendam sampel dalam metanol, lalu dikocok menggunakan shaker selama 48 jam pada temperatur ruangan. Kemudian dilakukan penyaringan untuk memisahkan ekstrak dengan bahan tumbuhan. Setelah itu ekstrak dipekatkan menggunakan alat vacuum rotary evaporator pada suhu $30-40^{\circ} \mathrm{C}$, sehingga diperoleh ekstrak kasar.

\section{Pengujian Fitokimia}

Pengujian fitokimia dilakukan dengan uji perubahan warna yang mengaju pada Harborne (1987) dan Kokate (2001) untuk menguji adanya senyawa aktif yang meliputi:

\section{a. Pengujian alkaloid (Kokate, 2001)}

Sebanyak $5 \mathrm{ml}$ ekstrak ditambahkan 2 $\mathrm{ml} \mathrm{HCl}$, kemudian dimasukkan $1 \mathrm{ml}$ larutan Dragendorff. Perubahan warna larutan menjadi jingga atau merah mengindikasikan bahwa ekstrak mengandung alkaloid.

\section{b. Pengujian flavonoid (Kakote, 2001)}

Sebanyak $1 \mathrm{ml}$ ekstrak tumbuhan diberikan beberapa tetes natrium hidroksida encer, munculnya warna kuning yang jelas pada larutan ekstrak dan menjadi tidak berwarna setelah penambahan asam encer $(\mathrm{HCl} 1 \%)$ mengindikasikan adanya flavonoid.

\section{c. Pengujian saponin (Harborne, 1987)}

Pengujian dilakukan dengan memasukkan $10 \mathrm{ml}$ air panas kedalam tabung reaksi yang beisi $1 \mathrm{ml}$ sampel uji yang telah dilarutkan dalam aseton. Selanjutnya larutan didinginkan dan dikocok selama 10 detik. Terbentuknya buih selama kurang lebih selama 10 menit dengan ketinggian $1-10 \mathrm{~cm}$ dan tidak hilang bila ditambahkan 1 tetes $\mathrm{HCl}$ $2 \mathrm{~N}$ menandakan bahwa ekstrak yang diuji mengandung saponin.

\section{d. Pengujian tanin (Kakote, 2001) \\ Pengujian dilakukan dengan} memasukkan $10 \mathrm{ml}$ larutan ekstrak kedalam tabung reaksi dan ditambahkan larutan timbal asetat $(\mathrm{CH} 3 \mathrm{COO}) 2 \mathrm{~Pb} 1 \%$. Tanin dinyatakan positif apabila pada reaksi terbentuk endapan kuning.

\section{e. Pengujian triterpenoid dan steroid (Harborne, 1987)}

Identifikasi dilakukan dengan melakukan campuran asam asetat ahidrid dan asam sulfat pekat yang biasa dikenal pereaksi Liebermann-Burchard. Pada pengujian ini 10 tetes asam asetat ahidrid dan 2 tetes asam sulfat pekat ditambahkan secara berurutan kedalam $1 \mathrm{ml}$ sampel uji yang telah dilarutkan dalam aseton. Selanjutnya sampel uji dikocok dan dibiarkan beberapa menit. Reaksi yang terjadi diikuti dengan perubahan warna, apabila terlihat warna merah dan ungu maka uji dinyatakan positif untuk triterpenoid dan apabila terlihat warna hijau dan biru maka uji dinyatakan positif pada streroid.

\section{Pengujian Aktivitas Antioksidan}

Pengujian aktivitas antioksidan dilakukan dengan mengacu pada metoda Arung (2008). Menggunakan spektrofotomerer pada suhu kamar $\left(25^{\circ} \mathrm{C}\right)$ dengan panjang glombang $517 \mathrm{~nm}$ dan larutan DPPH (1,1-diphenyl-2-picrylhydrazyl) digunakan sebagai radikal bebas, serta Ascorbic acid sebagai kontrol positif.

Ekstrak etanol daun ulin dibuat menjadi lima seri konsentrasi, kemudian ditambahkan larutan DPPH $0.1 \mathrm{mM}$. Sampel diinkubasi selama 25 menit dengan ruangan yang minim cahaya pada suhu ruangan, setelah itu diukur absorbansinya. Aktivitas antioksidan dari ekstrak sampel ditentukan berdasarkan persentase daya hambat relatif terhadap kontrol yang menggunakan persamaan sebagai berikut : (Cefarelli et al.,2006).

$$
\% \text { Inhibisi }=\frac{A D P P H-A \text { Sampel }}{A D P P H} \times 100
$$

\section{$\mathrm{A}=$ Absorbansi panjang glombang $517 \mathrm{~nm}$}

Selanjutnya data dihitung dengan persamaan regresi linier berdasarkan rumus $y=a+b x$ dengan metode probit. Persamaan regresi linier digunakan untuk menghitung IC 50 . (Nurfiana dkk., 2017).

Tabel 1. Tingkat Kekuatan Antioksidan dengan Metode DPPH (Pharmascience, 2019)

\begin{tabular}{cc}
\hline Intensitas & Nilai IC50 (ppm) \\
\hline Kuat & $<100$ \\
Sedang & $101-250$ \\
Lemah & $250-500$ \\
Tidak Aktif & $>500$ \\
\hline
\end{tabular}




\section{HASIL DAN PEMBAHASAN}

\section{Fitokimia}

Hasil penapisan fitokimia yang disajikan pada tabel 2 memperlihatkan bahwa daun ulin baik daun muda maupun daun tua memiliki potensi fitokimia yang cukup baik. Pada daun ulin muda maupun daun ulin tua keduanya mengandung flavonoid, tanin, saponin dan tritervenoid.

Tabel 2. Hasil Penapisan Fitokimia

\begin{tabular}{lcc}
\hline \multirow{2}{*}{ Perlakuan } & \multicolumn{2}{c}{ Hasil Pengamatan } \\
\cline { 2 - 3 } & Daun Muda & Daun Tua \\
\hline Uji Alkaloid & - & - \\
\hline Uji Flavonoid & + & + \\
\hline Uji Saponin & + & + \\
\hline Uji Tanin & + & + \\
\hline Uji Terpenoid/ & + & + \\
Steroid & (Terpenoid) & (Terpenoid) \\
\hline
\end{tabular}

Keterangan :

$(-) \quad=$ Tidak Terdeteksi

$(+)=$ Terdeteksi

Flavonoid terdeteksi pada daun ulin yang direaksikan dengan $\mathrm{NaOH}$, larutan berubah menjadi warna kuning. Perubahan warna ini disebabkan senyawa ari golongan flavonoid termasuk senyawa fenol yang apabila direaksikan dengan basa akan terbentuk warna yang disebabkan terjadinya sistim konyugasi dari gugus aromatic (Kusnadi dan Devi 2017). Keberadaan flavonoid dalam tumbuhan juga dinyatakan olek Totok (2013) bahwa flavonoid adalah kelompok senyawa polyphenol yang secara alami terdapat pada buah-buahan, sayuran, kacang-kacangan, biji, bunga, daun, kulit, pohon, dan lain-lain. Flavonoid termasuk salah satu klompok senyawa aromatik yang termasuk polifenol dan mengandung antioksidan. Flavonoid adalah senyawa yang terdiri dari 15 atom karbon yang umumnya tersebar didunia tumbuhan. Flavonoid tersebar luas ditanaman mempunyai banyak fungsi. Flavonoid adalah figmen tanaman untuk memproduksi warna bunga merah atau biru figmentasi kuning pada kelopak yang digunakan untuk menarik hewan penyerbuk. Manfaat flavonoid antara lain untuk melindungi struktur sel, meningkatkan efektifitas vitzmin $\mathrm{C}$, anti inflamasi, mencegas kropos tulang dan sebagai antibiotik (Lumbessy dkk., 2013).

Saponin adalah jenis senyawa kimia yang berlimpah dalam berbagai spesies tumbuhan senyawa ini merupakan glikosida amfipatik yang dapat mengeluarkan busa jika dikocok dengan kencang didalam larutan dan busanya bersifat setabil tidak mudah hilang. Senyawa saponin terdeteksi pada daun ulin, baik yang muda maupun yang tua.. Saponin memiliki glikosil yang berfungsi sebagai gugus polar. Senyawa yang memiliki gugus polar dan nonpalar bersifat aktif permukaan sehingga saat dikocok dengan air, saponin dapat membentuk misel. Pada struktur misel gugus polar menghadap ke luar sedangkan gugus nonpolarnya menghadap ke dalam. Keadaan inilah yang tampak seperti busa, karena itu dalam analisis ini dilihat kemampuan sampel dalam membentuk busa (Sangi., dkk., 2008)

Hasil analisis tanin terhadap ekstrak daun ulin menunjukkan bahwa dalam ekstrak sempel terdeteksi tannin, ditandai dengan terbentuknya endapan kuning pada saat ekstrak sampel direaksikan dengan larutan $\mathrm{Pb}$ Asetat 1\% Tanin biasanya dijumpai pada hampir semua tumbuhan hijau dan biasanya terdapat lebih banyak pada kulit kayu Semain banyak kandungan tanin maka semakin besar aktivitas antioksidannya karna tanin tersusun dari senyawa polifenol yang memiliki aktivitas penangkap radikal bebas (Lenny., 2006). Tanin merupakan senyawa aktif metabolit sekunder yang diketahui mempunyai beberapa khasiat yaitu sebagai astringen, anti diare, anti bakteri, dan antiolsidan.

Pada Analisis analisis steroid dan terpenoid ini didasarkan pada kemampuan senyawa terpenoid dan steroid membentuk warna oleh $\mathrm{H} 2 \mathrm{SO} 4$ pekat dalam pelarut anhidrida asam asetat. Pada ekstrak daun ulin terdeteksi terpenoid karena terbentuk warna merah ungu pada saat direaksikan dengan Liebermann-Burchard. Hal ini didasari oleh kemampuan senyawa triterpenoid dan steroid membentuk warna oleh $\mathrm{H} 2 \mathrm{SO} 4$ dalam pelarut asam asetat anhidrid. Perbedaan warna yang dihasilkan oleh terpenoid dan streoid disebabkan perbedaan gugus pada atom C-4 (Marliana dan Saleh, 2011).

. Terpenoid adalah salah satu senyawa metabolit sekunder yang terkandung dalam 
tanaman, senyawa tersebut dapat dijumpai pada bagian akar, batang, daun, buah, maupun biji tanaman. Sebagian besar senyawa triterpenoid memiliki kegiatan fisiologi yang menonjol sehingga dalam kegiatan sehari-hari banyak digunakan sebagai obat seperti untuk pengobatan penyakit diabetes, gangguan menstruasi, patukan ular, gangguan kulit, kerusakan hati dan malaria. Sedangkan tumbuhan yang mengandung senyawa terpenoid terdapat nilai ekologi karna senyawa ini bekerja sebagai antifungus, insektisida, anti pemangsa, anti bakteri dan anti virus.

\section{Antioksidan}

Pada penelitian ini pengujian aktivitas antioksidan dilakukan pada daun ulin muda dan daun ulin tua menggunakan UV-Vis spektrophotometer dan DPPH sebagai radikal bebas. Senyawa pembanding atau positive control yang digunakan adalah Ascorbic Acid atau vitamin C, merupakan senyawa antioksidan alami yang sering digunakan sebagai senyawa pembanding dalam pengujian aktivitas antioksidan, karena senyawa antioksidan alami relatif aman dan tidak menimbulkan toksisitas (Lung dan Destiani, 2017).

Tabel 3. Nilai $I_{50}$ Daun Ulin dan Ascorbic Acid

\begin{tabular}{ccc}
\hline & $\begin{array}{c}\mathrm{IC}_{50} \\
(\mathrm{ppm})\end{array}$ & $\begin{array}{c}\text { Persamaan Garis } \\
\text { Regresi Linier }\end{array}$ \\
\hline $\begin{array}{c}\text { Daun } \\
\text { Muda }\end{array}$ & 22.93 & $\mathrm{y}=0.4922 \mathrm{x}+38.712$ \\
\hline $\begin{array}{c}\text { Daun } \\
\text { Tua }\end{array}$ & 13.31 & $\mathrm{y}=3.055 \mathrm{x}+9.3389$ \\
\hline $\begin{array}{c}\text { Ascorbic } \\
\text { Acid }\end{array}$ & 7.08 & $\mathrm{y}=7.0567 \mathrm{x}-0.5823$ \\
\hline
\end{tabular}

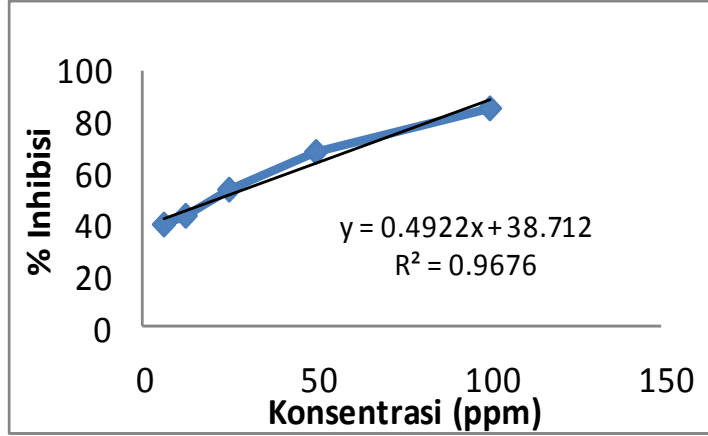

Gambar 2. Kurva Regresi Linier Ekstrak Daun Ulin Muda

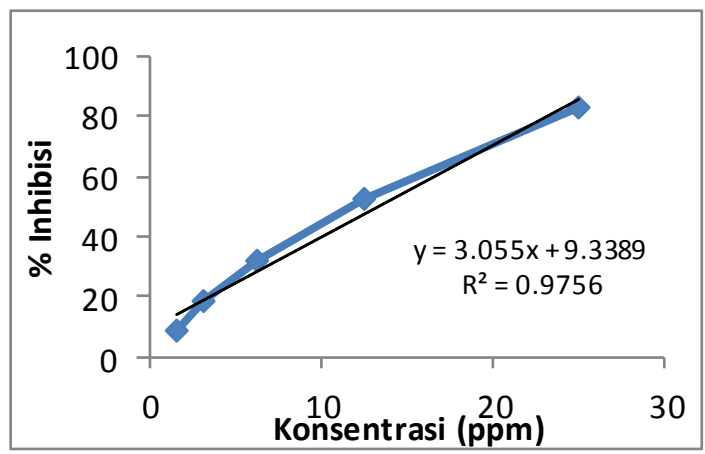

Gambar 3. Kurva Regresi Linier Ekstrak Daun Ulin Tua

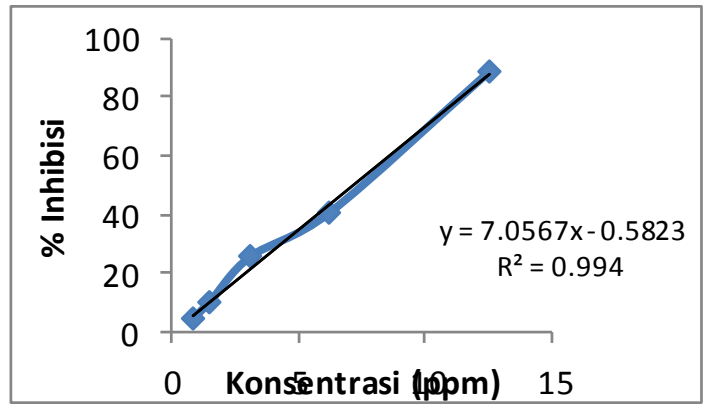

Gambar 4. Kurva Regresi Linier Ascorbic Acid

Analisis aktivitas antioksidan ekstrak daun ulin menggunakan metode DPPH dengan Ascorbic Acid sebagai kontrol positif, dimana parameter dari metode ini adalah nilai Inhibition Concrentation $\left(\mathrm{IC}_{50}\right)$ yaitu nilai konsentrasi yang dapat meredam 50\% aktivitas radikal bebas dimana $\mathrm{DPPH}$ berfungsi sebagai radikal bebas.

Hasil penelitian yang disajikan pada Tabel 3 terlihat bahwa $I_{50}$ daun ulin muda sebesar $22.93 \mathrm{ppm}$ dan daun ulin tua sebesar 13.31 ppm. Sedang nilai IC50 pada kontrol positif Ascorbic Acid sebesar 7.08 ppm. Hubungan konsentrasi larutan ekstrak daun ulin terhadap \% inhibisi ditunjukkan pada gambar 2 dan gambar 3, sehingga akan diperoleh persamaan regresi linier

$$
y=b x+a \text {. }
$$

Dengan diperolehnya persamaan garis linier maka dapat diletahui konsentrasi minimum yang dapat meredam $50 \%$ radikal bebas.

Prinsip kerja dari metode DPPH ini adalah proses reduksi senyawa radikal bebas DPPH (1,1-diphenyl-2- pycrilhydrazil) oleh antioksidan. Proses reduksi ditandai dengan perubahan warna larutan, yaitu dari warna 
ungu pekat (senyawa radikal bebas) menjadi warna kuning (senyawa radikal bebas yang tereduksi oleh antioksidan). Pemudaran warna akan mengakibatkan penurunan nilai absorbansi sinar tampak dari spektrofotometer, sehingga semakin rendah nilai absorbansi maka semakin tinggi aktivitas antioksidannya (Purwanti.dkk., 2009).

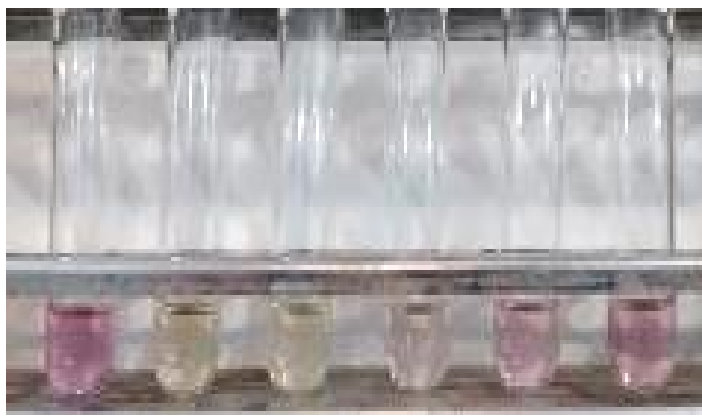

Gambar 5. Perubahan Warna DPPH Pada Seri Konsentrasi Ekstrak Daun Ulin Muda

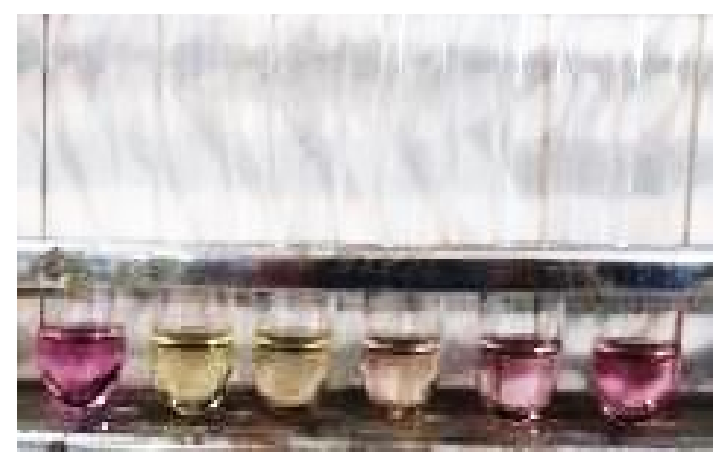

Gambar 6. Perubahan Warna DPPH Pada Seri Konsentrasi Ekstrak Daun Ulin Tua

Aktivitas antiokdidan daun ulin baik yang muda maupun yang tua termasuk kategori kuat karena $\mathrm{IC}_{50}$ dibawah 100 ppm. Indikasi kuatnya aktivitas antioksidan salah satunya ditandai dengan adanya metabolit sekunder salah satunya yaitu flavonoid yg memiliki potensi antioksidan yang mampu meredam radikal bebas. Selain itu senyawa flavonoid juga diketahui dapat mengurangi risiko terjadinya penyakit jantung dan kanker (Hanin dan Pratiwi., 2017).

Antioksidan daun ulin tua dengan $\mathrm{IC}_{50}$ sebesar $13.31 \mathrm{ppm}$ lebih kuat dibanding daun ulin muda dengan $\mathrm{IC}_{50}$ sebesar 22.93ppm, hal ini dipengaruhi oleh kandungan metabolit sekunder yang ada di dalam daun, dimana metabolit sekunder pada daun tua sudah terakumulasi sehingga kekuatan antioksidannya semakin meningkat (Bahriul.dkk., 2014) Namun demikian daun ulin muda dan daun ulin tua keduanya memiliki aktivitas antioksidan yang kuat yang mendekati kontrol positif Ascorbic Acid dengan $\mathrm{IC}_{50}$ sebesar $7.08 \mathrm{ppm}$.

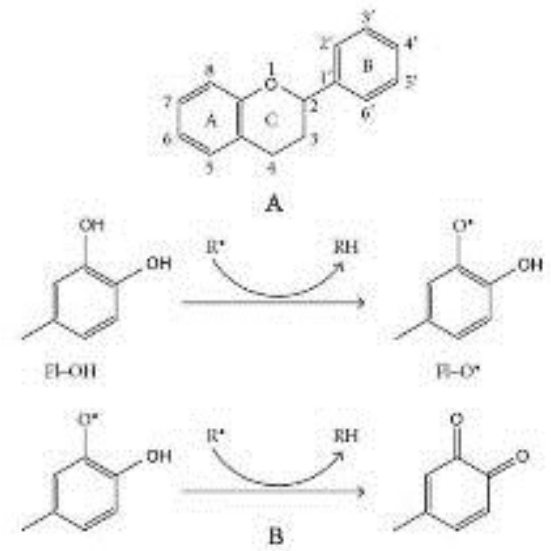

Gambar 7. Peredaman Radikal Bebas oleh Flavonoid

\section{KESIMPULAN}

Daun ulin potensial sebagai antioksidan alami dimana daun muda dan daun tua memiliki aktivitas antioksidan yang kuat dengan $\mathrm{IC}_{50}$ yang diperoleh masing-masing 22.93ppm dan $13.31 \mathrm{ppm}$.

\section{DAFTAR PUSTAKA}

Arung E.T, Muladi S, Sukaton E, Shimizu K and Kondo R. (2008). Artocarpin, a promising compound as whitening agent and anti-skin cancer. J Trop Wood Sci Technol, 6, 33-36.

Bahriul.P, Rahman.N., Diah..W.M., Uji Aktivitas Antioksidan Ekstrak Daun Salam (Syzogium polyanthum) Dengan Menggunakan 1,1-Difenil-2Pikrilhidrazyl. J Akad. Kim.3(3)

Cefarelli G, Abrosca BD, Fiorentino A, Izzo A, Mastellone C, Pacifica S and Piscopo V. (2006). Free-radical scavenging and antioxidant activities of secondary metabolites from reddened cV. Annurca apple fruits. J Agric Food Chem, 54(3)

Cahyadi, Wisnu. (2009), Bahan Tambahan Pangan, Bumi Aksara. Jakarta: 
Harborne, J.B. 1987. Metode Fitokimia (Terjemah). Terbitan Ke-2 Penerbit ITB. Bandung

Hanin.N.N.F., Pratiwi.R. 2017. Kandungan Fenolik, Flavonoid dan Aktivitas Antioksidan Ekstrak Vol. 2 Daun Paku Laut (Acrostichum aureum L.)

Hidayat.S., Cahyaningsih. R., Safarinanugraha.D., $\quad$ Fijridiyanto.I.A., Fertil dan Steril. J. Trop. Biodiv. Biotech., Dayana.I., (2016). Jalur Wisata Tumbuhan Obat Di Kebun Raya Bogor, LIPI Press

Juniarti, Osmeli, D., \& Yuhernita. (2009). Kandungan senyawa kimia, uji toksisitas (Brine shrimp lethality test) dan antioksidan (1,1-diphenyl-2pikrilhydrazyl) dari ekstrak daun saga (Abrus precatorius L.). Makara Sains, 13(1), 50-54

Kokate CK. (2001). Pharmacognosy. 16th ed. Nirali Prakasham, Mumbai, India.

Kusnadi, Devi.E.T., (2017). Isolasi dan Identifikasi Senyawa Flavonoid Pada Ekstrak Daun (Apium graveolens L.) Dengan Metode Refluks. Pancasakti Science Education Journal

Lenny, S. 2006. Senyawa Flavonoida, Fenilfropanoida dan Alkaloida. Karya IImiah. Fakultas Matematika dan IImu Pengetahuan Alam. Universitas Sumatra Utara,Medan.

Lumbessy.M., Abidjulu.J., Paendong. J.J.E. (2013). Uji Total Flavonoid Pada Beberapa Tanaman Obat Tradisonal Di Desa Waitina Kecamatan Mangoli Timur Kabupaten Kepulauan Sula Provinsi Maluku Utara. Jurnal MIPA UNSRAT Online 2 (1) 50-55

Lung.J.K.S.,Destiani.D.P. (2017) Uji Aktivitas Antioksidan Vitamin A,C,E dengan metode DPPH. Suplemen Volume 15 Nomor 1.

Marliana, S.D., Saleh, C.(2011). Uji Fitokimia dan Aktivitas Antibakteri Ekstrak Kasar Etanol, Fraksi nHeksana, Etil asetat, dan Metanol dari Buah Labu Air (Lagenari Siceraria (Morliana). J. Kimia Mulawarman

Purwanti.L, Dasuki.U.A, Imawan.A.R., (2009). Perbandingan Aktivitas Antioksidan Dari Seduhan 3 Merk The Hitam (Camellia sinensis (L.) Kuntze) Dengan Metode Seduhan Berdasarkan
SNI 01-1902-1995 Jurnal IImiah Farmasi Farmasyifa Volume 2 No 1

Sangi.M, Runtuwene.M.R.J. , Simbala.H.E.I. dan Veronica M. A. (2008). Analisis Fitokimia Tumbuhan Obat Di Kabupaten Minahasa Utara, Chem. Prog. Vol. 1, No. 1

Utomo, A. B., Suprijono, A., \& Risdianto, A. (2008). Uji aktivitas antioksidan kombinasi ekstrak sarang semut (Myrmecodia pendans) dan ekstrak teh hitam (Camellia sinensis O.K.var.assamica (mast.)) dengan metode DPPH (1,1-difenil-2pikrilhidrazil). http://journal.stifar.ac.id/ojs/ index.php/js/article/viewFile/6/7 